\title{
CORRIGENDUM
}

\section{Increasing forest disturbances in Europe and their impact on carbon storage}

Rupert Seidl, Mart-Jan Schelhaas, Werner Rammer and Pieter Johannes Verkerk

Nature Climate Change 4, 806-810 (2014); published online 3 August 2014; corrected online 8 August 2014; corrected after print 4 September 2014.

In the version of this Letter previously published, the value given for net ecosystem productivity was incorrect, and should have read 99.2 $\mathrm{Tg} \mathrm{C} \mathrm{yr}^{-1}$; this has no impact on the reported results. These corrections have been made in the online versions of the Letter. 